\title{
Relationship Between Indices of Oxidative Stress, Endothelial Dysfunction and Chaperone Activity and the Severity of Coronary Atherosclerosis
}

\author{
Julia A. Kotova, PhD*; Anna A. Zuikova, PhD, ScD; Alexander N. Pashkov, PhD, ScD; \\ Natalia V. Strahova, PhD; Olga N. Krasnorutskaya, PhD \\ Voronezh State Medical University named after N.N. Burdenko \\ Voronezh, the Russian Federation
}

\begin{abstract}
The aim of this research was to study the relationship between the indices of oxidative stress, endothelial dysfunction and chaperone activity of proteins with the severity of coronary atherosclerosis. In patients with coronary heart disease, we found gender-related differences in the severity of coronary atherosclerosis. Significant differences in the indices of oxidative stress, endothelial dysfunction and chaperone activity were revealed depending on the severity of coronary atherosclerosis and the type of atherosclerotic lesion. The determination of studied parameters can serve as a good indicator of the severity of coronary atherosclerosis.(International Journal of Biomedicine. 2018;8(3):182-185.)
\end{abstract}

Key Words: coronary heart disease $\bullet$ endothelial dysfunction $\bullet$ oxidative modification of proteins $\bullet$ superoxide dismutase

\section{Abbreviations}

ADPH, aldehyde derivative of DNPH; CHD, coronary heart disease; CAG, coronary angiography; DNPH, 2.4-dinitrophenylhydrazine; Hsp27, heat shock protein 27; OS, oxidative stress; KDPH, ketone derivative of DNPH; OMP, oxidative modification of proteins; PCC, protein carbonyl content; SOD, superoxide dismutase.

\section{Introduction}

Although the complex mechanisms of the development of coronary atherosclerosis are not completely understood, recent advances have established a fundamental role for inflammation and oxidative stress in this process. ${ }^{(1-4)}$ Oxidative modification of low-density lipoprotein has a central role in the initial phase of the atherosclerotic process. In CHD, a decrease in intracellular protection against reactive oxygen species, primarily due to a decrease in the level of SOD - the key enzyme of the antioxidant system - has been demonstrated by a number of researchers. ${ }^{(5)}$ The imbalance between pro-oxidants and antioxidants leads to oxidative damage of proteins - an

*Corresponding author: Julia A. Kotova, PhD Voronezh State Medical University named after N.N. Burdenko. Voronezh, the Russian Federation. E-mail: kotova_u@inbox.ru early indicator of the cell damage. ${ }^{(6,7)}$ Oxidants induce the posttranslational modification of proteins. ${ }^{(8)}$ Peroxide treatment of rat cardiac myocytes rapidly induces phosphorylation of Hsp27, which increases the activity of Hsp27.(9) The activation of Hsp70 may play a role in protecting the cells against oxidative stress and inflammatory damage. ${ }^{(10)}$ In addition, homocysteine (Hcy) is an established biomarker for endothelial dysfunction and vascular disease, and is linked to increased OS. ${ }^{(11)}$

The aim of this research was to study the relationship between the indices of oxidative stress, endothelial dysfunction and chaperone activity of proteins with the severity of coronary atherosclerosis.

\section{Materials and Methods}

We examined 93 CHD patients ( 33 women and 60 men, mean age of $61.8 \pm 8.1$ ) who had coronary atherosclerosis of 
varying degrees, according to coronary angiography (CAG).

Exclusion criteria were myocardial infarction within previous 3 months, diabetes mellitus requiring insulin treatment, arterial hypertension (BP>159/99 mmHg), hypotension (blood pressure $<100 / 60 \mathrm{mmHg}$ ), atrial fibrillation and life-threatening ventricular arrhythmias, valvular heart disease, long time treatment with lipid-lowering drugs and ACE inhibitors, chronic heart failure (NYHA FC $>$ II), chronic renal and hepatic failure.

All patients underwent the following examinations: assessment of traditional risk factors (high blood pressure, smoking, body mass index, diabetes), physical examination, clinical and biochemical laboratory methods, 12-lead ECG, echocardiography, Holter ECG monitoring, treadmill test, and coronary angiography. Blood samples were obtained in the morning after a $12 \mathrm{~h}$ overnight fast. Total cholesterol (TC), low-density lipoprotein cholesterol (LDL-C), highdensity lipoprotein cholesterol (HDL-C), triglycerides (TG), ALT, AST, CFK, apolipoprotein A (ApoA), apolipoprotein B (ApoB), high-sensitivity C-reactive protein (hsCRP), fibrinogen, ESR, WBC were determined in plasma using "Daytona" analyzer (RANDOX, Ireland).

CAG was performed by the Judkins technique using General Electric Innova 3100 (GE Healthcare, USA). In collegial analysis of CAG data, we determined the type of coronary blood supply and noted the number of affected coronary arteries, localization, and type of stenotic narrowing. To assess the degree of narrowing of vessels, a visual assessment was used with the following characteristics: normal coronary artery, changing contours of artery without determining the degree of stenosis, luminal stenosis as minimal $(<25 \%$ stenosis), mild (25\% to $49 \%$ stenosis), moderate (50\% to $69 \%$ stenosis), severe (70\% to $100 \%$ stenosis). ${ }^{(12)}$ Finding a $\geq 70 \%$, "severe" stenosis, was an indicator for revascularization. According to the degree of stenosis, 3 groups were formed: Group I included 22 patients with minimal-mild stenosis; Group II included 50 patients with moderate stenosis; Group III included 21 patients with severe stenosis. Morphologic characteristics of the lesion were evaluated by applying ACC/ AHA morphology criteria $^{(13)}$ : Type A in 15 patients, Type $\mathrm{B}$ - in 57 patients, and Type $\mathrm{C}-$ in 21 patients. All patients were divided also into 3 groups according to the number of affected vessels: Group 1 included 22 patients $(3$ men and 19 women) with insignificant stenotic lesions; Group 2 included 41 patients ( 30 men and 11 women) with single- or two-vessel lesions; Group 3 included 30 patients (26 men and 4 women) with three-vessel or more multivessel lesions.

OMP was identified by PCC. Carbonyl groups formed from oxidation with 2.4-dinitrophenylhydrazine (DNPH) were estimated using the methods by Levine et al. ${ }^{(14)}$ with modifications by Dubinina et al. ${ }^{(15)}$ The assay is based on the spectrophotometric detection of the reaction between DNPH with protein carbonyl to form protein hydrazone. The optical density of 2,4-dinitrophenylhydrazones derivates was recorded on an SF-36 spectrophotometer. The optical density of aldehyde- and ketone derivatives of a neutral character was recorded at $356 \mathrm{~nm}$ and $370 \mathrm{~nm}$, respectively (ADPHn and KDPHn). The optical density of aldehyde- and ketone derivatives of a basic character was recorded at 430nm and $530 \mathrm{~nm}$, respectively (ADPHb and $\mathrm{KDPHb}$ ). The SOD activity was determined by the spectrophotometric method.

The serum level of L-Hcy was determined by EIA using «Axis-Shield» test kit. Chaperone activity was measured by monitoring the DTT-induced aggregation of insulin in the absence and presence of Hsp27. ${ }^{(16)}$

Statistical analysis was performed using statistical software package SPSS version 20.0 (SPSS Inc, Chicago, IL). Quantitative parameters are presented as Median (Me) and $25^{\text {th }}$ and $75^{\text {th }}$ percentiles as Inter Quartile Range (IQR). The Kruskal-Wallis $\mathrm{H}$ test was used to compare medians among 3 comparison groups. Spearman's correlation coefficient $\left(\mathrm{r}_{\mathrm{s}}\right)$ was used to determine the strength and direction of association between two variables. A probability value of $P<0.05$ was considered statistically significant.

The study was approved by the Voronezh State Medical University Ethics Committee. Written informed consent was obtained from all patients.

\section{Results and Discussion}

A statistical relationship between the sex and the number of affected vessels was determined: an insignificant lesion was more common in women, two-vessel lesions - in men (72.7\%); the three-vessel or multivessel lesions were predominant in men (87.5\%) (Figure 1). Comparison of the indices in the three groups revealed significant differences in the L-Hcy level $(P=0.000)$, SOD activity $(P=0.015)$, chaperone activity $(P=0.011)$, blood levels of ADPHn $(P=0.003)$ and KDPHn $(P=0.028)$ (Table 1$)$.

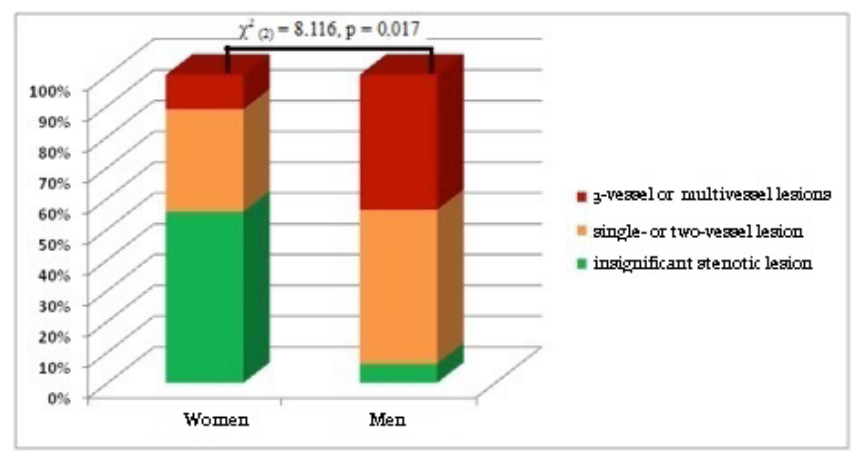

Fig. 1. Statistical relationship between the sex and the number of affected vessels.

The level of shaper activity was 78.8\% [60.6\%; 82.5\%], $72.4 \%[67.4 \% ; 75.3 \%]$ and $68.3 \%$ [60\%; 68.3\%] in Groups I, II, and III, respectively. At the same time, the level of L-Hcy was $9.6 \mu \mathrm{mol} / \mathrm{ml}[8.1 \mu \mathrm{mol} / \mathrm{ml} ; 9.9 \mu \mathrm{mol} / \mathrm{ml}], 10.2 \mu \mathrm{mol} / \mathrm{ml}$ $[9.8 \mu \mathrm{mol} / \mathrm{ml} ; 10.7 \mu \mathrm{mol} / \mathrm{ml}]$ and $11.4 \mathrm{~mol} / \mathrm{ml}[10.4 \mu \mathrm{mol} / \mathrm{ml}$; $12 \mu \mathrm{mol} / \mathrm{ml}]$ in Groups I, II, and III, respectively. The highest SOD activity was found in Group I: 41.7\% [39.1\%; 47.3\%]. We revealed a significant difference in this indicator among Groups I, II, and III $(P=0.003)$. When evaluating PCC, a significant difference was established between these groups in levels of ADPHn $(P=0.001)$ and KDPHn $(P=0.025)$. The levels of $\mathrm{ADPHb}$ and $\mathrm{KDPHb}$ were without significant differences. 
Table 1.

Biomarkers of CHD and the number of affected vessels

\begin{tabular}{|l|c|c|c|c|}
\hline \multicolumn{1}{|c|}{ Variable } & Group $1(\mathrm{n}=22)$ & Group $2(\mathrm{n}=41)$ & Group $3(\mathrm{n}=30)$ & $P$-value \\
\hline L-Hcy, $\mu \mathrm{mol} / \mathrm{ml}$ & $9.588 .11 ; 9.97]$ & $10.43[10.10 ; 11.39]$ & $12.3[11.61 ; 12.49]$ & 0.000 \\
\hline SOD acivity, \% & $41.7[39.0 ; 47.4]$ & $35.2[32.8 ; 36.0]$ & $32.3[30.7 ; 39.2]$ & 0.015 \\
\hline Chaperone activity, \% & $78.8[60.6 ; 82.5]$ & $68.3[66.7 ; 76.9]$ & $60.0[55.4 ; 68.2]$ & 0.011 \\
\hline ADPHn, IU/mg & $22.3[21.5 ; 23.3]$ & $24.8[23.5 ; 25.7]$ & $27.0[24.8 ; 27.9]$ & 0.003 \\
\hline KDPHn, IU/mg & $19.9[18.3 ; 20.8]$ & $21.0[20.3 ; 22.3]$ & $23.5[20.8 ; 25.0]$ & 0.028 \\
\hline ADPHb, IU/mg & $10.7[9.2 ; 11.8]$ & $11.3[10.9 ; 11.8]$ & $10.8[9.6 ; 12.1]$ & 0.493 \\
\hline KDPHb, IU/mg & $6.2[2.4 ; 9.2]$ & $6.8[6.6 ; 8.8]$ & $8.8[7.2 ; 9.5]$ & 0.234 \\
\hline
\end{tabular}

Chaperone activity depended on the type of morphologic characteristics of the lesion $(P=0.002)$. Thus, the lowest activity was observed in patients with Type C. Similar changes were detected for SOD activity; a significant difference $(P=0.004)$ was also revealed between the groups with Type $\mathrm{A}, \mathrm{B}$, and $\mathrm{C}$. When assessing the level of L-Hcy and PCC, the opposite tendency was identified: the more complicated the atherosclerotic plaque, the higher the studied parameter levels. At the same time, significant differences were found in the level of L-Hcy $(P=0.000)$, ADPHn $(P=0.05)$ and KDPHn $(P=0.001)$.

Correlation analysis revealed the relationships between the number of affected arteries and the blood levels of L-Hcy $\left(\mathrm{r}_{\mathrm{s}}=0.843, P=0.000\right)$, ADPHn $\left(\mathrm{r}_{\mathrm{s}}=0.671, P=0.002\right), \mathrm{KDPHn}$ $\left(\mathrm{r}_{\mathrm{s}}=0.544, P=0.005\right)$, SOD activity $\left(\mathrm{r}_{\mathrm{s}}=-0.545, P=0.005\right)$, and chaperone activity $\left(\mathrm{r}_{\mathrm{s}}=-0.616, P=0.001\right)$; the correlations with the levels of ADPHb and KDPHb were weak and not significant $\left(\mathrm{r}_{\mathrm{s}}=-0.076, P=0.717\right.$ and $\mathrm{r}_{\mathrm{s}}=0.309, P=0.132$, respectively). The same patterns were found in the group of patients with severe stenosis (Group III).

\section{Conclusion}

In CHD patients, we found gender-related differences in the severity of coronary atherosclerosis. Significant differences in the indices of OS, endothelial dysfunction and chaperone activity were revealed depending on the severity of coronary atherosclerosis and the type of atherosclerotic lesion. The determination of studied parameters can serve as a good indicator of the severity of coronary atherosclerosis.

\section{Competing interests} interests.

The authors declare that they have no competing

\section{Sources of Funding}

This work was partially supported by the Council on Grants of the President of the Russian Federation for State Support of Young Scientists and Leading Scientific Schools (Grant MK-552.2018.7).

\section{References}

1. Ragino IuI, Cherniavskiı̌ AM, Eremenko NV, Shakhtshneǐder EV, Polonskaia IaV, Tsymbal SIu, et al. [Key laboratory diagnostic biomarkers of coronary atherosclerosis]. Kardiologiia. 2011;51(3):42-6. [Article in Russian].

2. Vertkin AL, Topolyanskii AV. [The problem of hyperhomocysteinemia in cardiac patients]. Pharmateca. 2007.(15):10-14. [Article in Russian].

3. Lvovskaya EI., Sakhankova EN. [The ratio of lipid peroxidation levels and oxidative modification of proteins in students aged 17-23 (Kungur)]. Vestnik YuUrGU. 2012;(21):112-116. [Article in Russian].

4. Musthafa QA, Abdul Shukor MF, Ismail NAS, Mohd Ghazi A, Mohd Ali R, M Nor IF, et al. Oxidative status and reduced glutathione levels in premature coronary artery disease and coronary artery disease. Free Radic Res. 2017 Oct;51(910):787-798. doi: 10.1080/10715762.2017.1379602.

5. Zanozina OV, Borovkov NN, Sherbatyuk TG. [Oxidized Modified Proteins in the Atherosclerosis Genesis at a Diabetes Mellitus of the 2nd Type]. Sovremennye tehnologii v medicine 2009;(2):72-75. [Article in Russian].

6. Bykova AA, Azizova OA, Dumikyan AS, Shvachko AG, Sergienko VI, Syrkin AL. [Oxidative modification of fibrinogen in patients with ischemic heart disease]. Russian Journal of Cardiology. 2015;1 Suppl 1:24. [Article in Russian]. 7. Fomina MA, Abalenikhina YuV. Oxidative modification of tissue proteins at changing the synthesis of nitric oxide. Moscow: "GEOTAR-Media"; 2018. [in Russian].

8. Wick G, Knoflach $\mathrm{M}, \mathrm{Xu}$ Q. Autoimmune and inflammatory mechanisms in atherosclerosis. Annu Rev Immunol. 2017; 22:361-403.

9. Cullingford TE, Wait R, Clerk A, Sugden PH. Effects of oxidative stress on the cardiac myocyte proteome: modifications to peroxiredoxins and small heat shock proteins. J Mol Cell Cardiol. 2006;40(1):157-72.

10. Ren J, Liu C, Zhao D, Fu J. The role of heat shock protein 70 in oxidant stress and inflammatory injury in quail spleen induced by cold stress. Environ Sci Pollut Res Int. 2018 May 15. doi: 10.1007/s11356-018-2142-8.

11. Davydchyk EV, Snezhitskiy VA, Nikonova LV. Relationship of hyperhomocysteinemia with coronary heart disease and diabetes mellitus. Journal of the Grodno State Medical University. 2015; (1):9-13.

12. Cheng V, Gutstein A, Wolak A, Suzuki Y, Dey D, Gransar $\mathrm{H}$, et al. Moving Beyond Binary Grading of Coronary Arterial 
Stenoses on Coronary Computed Tomographic Angiography: Insights for the Imager and Referring Clinician. JACC Cardiovasc Imaging. 2008; 1(4):460-471

13. Ryan TJ, Bauman WB, Kennedy JW, Kereiakes DJ, King SB III, McCallister BD, et al. Guidelines for percutaneous transluminal coronary angioplasty. A report of the American College of Cardiology/American Heart Association Task Force on Assessment of Diagnostic and Therapeutic Cardiovascular Procedures (Committee on Percutaneous Transluminal Coronary Angioplasty). J Am Coll Cardiol. 1993;22(7):2033-54
14. Levine RL, Garland D, Oliver CN, Amici A, Climent I, LenzAG, et al. Determination of carbonyl content in oxidatively modified proteins. Methods Enzymol. 1990;186:464-478.

15. Dubinina EE, Burmistrov SO, Khodov DA, Porotov IG. [Oxidative modification of human serum proteins. A method of determining it].Vopr Med Khim. 1995;41(1):24-6. [Article in Russian].

16. Lelj-Garolla B, Mauk AG. Self-association and chaperone activity of Hsp27 are thermally activated. J Biol Chem. 2006;281(12):8169-74. 